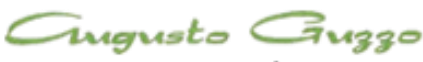

REVISTA ACADEMICA

\title{
El otro y su plasmación fantasmática: una lectura transversal de la blessure, de Nicolas Klotz
}

\author{
Fran Ayuso Ros ${ }^{1}$ \\ Recebido em: 10/09/2014. Aprovado em: 05/11/2014. Disponibilizado em: 26/12/2014
}

1. Fran Ayuso Ros es doctorado Departamento de Teoría de los Lenguajes Universidad de Valencia. Estudio General. Máster en Interculturalidad y Políticas Comunicativas en la Sociedad de la Información por la misma Universidad, con Premio Extraordinario. Licenciado en Comunicación Audiovisual por la Universitat de València franaros@alumni.uv.es.

\section{Resumen}

El fenómeno de la inmigración ocupa en la actualidad un lugar relevante en el conjunto de estrategias desplegadas por los líderes políticos. De tal manera que la demonización del inmigrante que trata por todos los medios de acceder a Europa en busca de una vida mejor supone una táctica en alza en aras de la rentabilidad electoral. Este proceso de criminalización, que se sustenta en presupuestos fuertemente anclados culturalmente, no es ajeno al ámbito cinematográfico. En $L a$ Blessure (2005), Elisabeth Perceval y Nicolas Klotz sitúan el foco en los mecanismos policiales de control que operan en los aeropuertos franceses y el modo en que estas políticas de exclusión afectan a un grupo de inmigrantes subsaharianos. Lo hacen poniendo en práctica un mecanismo formal que otorga espacio, voz y tiempo a aquellos que son rechazados, silenciados y expatriados. Aquellos que, al filtro de los tecnicismos administrativos, adquieren el estatuto de muertos vivientes. En este artículo, proponemos repasar las primeras producciones cinematográficas que dieron forma representativa a la figura del zombi para así trazar trayecto de lectura oblicuos que amplíen el horizonte de sentido proyectado en el film de Klotz.

Palabras clave: Cine; inmigración; forma; zombi; fantasmagoría; realidad; palimpsesto.

\begin{abstract}
The immigration phenomenon currently holds a relevant place in the set of strategies that are unfolded by political leaders. So much that the demonization of immigrants, who try to gain access to Europe by all possible means in search of a better life, constitutes a tactic which is on the rise for the sake of gaining votes. This process of criminalization that is based on preconceptions which are strongly culturally anchored is not alien to the world of cinema. In La Blessure (2005), Elisabeth Perceval and Nicolas Klotz focus in on police control mechanisms that operate in French airports and the way in which these policies of exclusion affect a group of sub-Saharan immigrants. They do so by putting a formal mechanism into practice which grants space, voice and time to those who are rejected, silenced and exiled. Those people who acquire the statute of the living dead through the filter of technical and administrative terms. In this article, we propose to revise the first cinematographic productions that shaped the
\end{abstract}


representative figure of the zombie, in order to give an oblique reading, which extends the horizon of the projected meaning in Klotr's film.

Keywords: Cinema, immigration, figure, zombie, phantasmagoric, reality, palimpsest.

ROS, F.A.: El otro y su plasmación fantasmática: una lectura transversal de la blessure, de Nicolas Klotz 


\section{Introducción}

El film La Blessure (2005), escrito por Elisabeth Perceval y realizado por Nicolas Klotz, se inserta, dentro de su obra conjunta, en lo que ellos mismos han denominado la "Trilogía de los tiempos modernos", junto a Paria (2000) y La cuestión humana (La question humaine, 2007). Un tríptico en el que se aborda el tema de la exclusión: la que sufre la gente sin hogar, los inmigrantes empobrecidos y todos aquellos que resultan improductivos desde la perspectiva de la rentabilidad empresarial. Un corpus que denuncia un sistema capitalista que genera restos, residuos, elementos superfluos, y cuya maquinaria se engrasa de forma espectacular mediante la redefinición constante del entorno simbólico.

La Blessure fue concebido en el proceso de investigación de lo que iba a ser una obra de teatro, a partir del libro de Jean-Luc Nancy El intruso. El film muestra la vida de un grupo de africanos en territorio francés, centrado, en primer término, en los controles y las vejaciones que padecen a su llegada al aeropuerto y, más tarde, en las precarias condiciones de vida del squat, un edificio ocupado con las ventanas tapiadas en el que conviven con refugiados procedentes de diferentes países y que la policía amenaza con derruir. Aunque de carácter eminentemente coral, la película avanza al ritmo que restañe la herida, física y moral, la protagonista femenina, Blandine. Un daño que motiva su reclusión en el interior del edificio hasta el momento en que decide romper su silencio, relatando las vejaciones sufridas a manos de la policía, y salir al exterior.

El cine de Nicolas Klotz apuesta por visibilizar personajes y situaciones que, por regla general, permanecen invisibles. Sus obras suponen un proyecto de investigación cinematográfica que se interroga sobre la capacidad del dispositivo fílmico para inscribir en él las huellas del tiempo, de plantear interrogantes que abran caminos a nuevos espacios de conocimiento, de crear realidades que ofrezcan pistas para entender esa otra realidad del día a día. Una indagación que desarrolla partiendo de la sospecha de que el debate de las ideas se articula a través de la reinvención de las formas, interrogándose acerca de cuál es el método más adecuado: ¿Cómo filmar la palabra, la palabra confiscada, la palavra acallada?, ¿cómo filmar los cuerpos de manera que se puedan sentir las pulsaciones de su cercanía?, ¿cómo filmar la violencia sin causar con ello todavía mas dolor, sin envilecer de nuevo los cuerpos?

En este orden de cosas, no podemos sustraernos a las palabras de Nicolas Klotz cuando define la trilogía antes mencionada como una trilogía sobre el léxico de la muerte de la época actual, y de la invención de un posible contra-léxico, de otro lenguaje.

Paria trata de los vagabundos, es decir, de cómo se evacúa la 'excrementalización' de ciertas zonas humanas. La Blessure es más luminosa: frente a la represión, por el contrario, cómo intentar aparecer y tomar forma. Las tres películas están habitadas por una misma esperanza, la creencia de que, gracias al cine, algunas cosas de la sociedad se pueden arreglar (Entrevista realizada por Emmanuel Burdeau y publicada en la revista Cabiers du cinéma España número 17, p. 21).

En sintonía con esa configuración de un contra-léxico, la contingencia de una denuncia política inscrita en La Blessure se dirime en la utilización que hace de los componentes de la puesta en escena: la insistencia del fuera de campo, la composición de los encuadres, el papel de los diferentes puntos de vista, el tratamiento de la violencia, el protagonismo de los cuerpos y la palabra, la construcción de un espacio y de un tiempo para que aquellos que son 
invisibilizados y callados tengan presencia y voz, la abstracción artística, el trabajo sobre las duraciones, la tensión entre las estrategias documentales y ficcionales, la inquietante presencia de lo fantástico, la elaborada fotografía, la postura ideológica adoptada por la enunciación y las resonancias musicales (Este supuesto es el que desarrollo en un artículo que se publicará en el número 7 de la revista Eu-topías, con el título "Formas en conflicto. Cómo la práctica cinematográfica participa de una experiencia revolucionaria en La Blessure, de Nicolas Klotz”).

\section{Marco conceptual y metodológico}

\subsection{El estatuto de lo fantástico y la puesta en duda de la realidad}

$\mathrm{Si}$ admitimos que toda obra artística parte de una sospecha, de una sospecha sobre la realidad, no nos costará reconocer que donde mejor se plasma esta preocupación es en el terreno de lo fantástico, de lo fantasmagórico. En su Introducción a la literatura fantástica, Tzvetan Todorov instauró una esquiva definición del género:

La ambigüedad se mantiene hasta el final de la aventura: ¿Realidad o sueño? ¿Verdad o ilusión? De este modo nos vemos arrastrados al corazón de lo fantástico. El fantástico ocupa el tiempo de esta incertidumbre. Desde el momento que escogemos una o la otra, abandonamos lo fantástico para entrar en un género vecino, lo extraño o lo maravilloso. El fantástico es la duda experimentada por un ser que sólo conoce las leyes naturales, frente a un acontecimiento aparentemente sobrenatural. (Todorov, 1970, p. 26)

El estatuto del género fantástico se sitúa, de esta manera, en un estadio entre lo cotidiano y lo maravilloso; entre la aparente familiaridad de lo que nos rodea y la extrañeza que esos mismos elementos nos provocan cuando nos desvelan sus zonas de sombra; entre el apacible sueño y el brusco despertar. Una fractura que pone en entredicho la natural presencia de las cosas. De ahí que la literatura fantástica se haya definido también como aquella que:

"presenta en forma de problema hechos a-normales, a-naturales o irreales. Pertenecen a ella las obras que ponen el centro de interés en la violación del orden terreno, natural o lógico, y por lo tanto en la confrontación de uno y otro orden dentro del texto, en forma explícita o implícita" (Barrenechea, 1972, p. 393)

De esta capacidad del género fantástico para interrogar acerca de esta ruptura del orden social ha dado buena cuenta el cine, sobre todo aquel que se adscribe como Serie $B$, al poner en escena unos seres que irrumpen desde el exterior para poner en cuestión el statu quo. Las décadas de los años 40 y 50 supusieron el período más fructífero de este cine, aquel en el que se sentaron las bases de un género (fantástico o de ciencia ficción) que continúa gozando de una gran aceptación. Películas que constituyen el espectro hollywoodiense de la Guerra Fría: la amenaza nuclear, los peligros de la experimentación científica y, sobre todo, la amenaza de invasión por parte del gran Otro: el comunismo.

Tomemos como ejemplo la película $L a$ invasion de los ladrones de cuerpos (Invasion of the Body Snatchers, Don Siegel, 1956). En ella se recrea, en forma de parábola fantástica, la paranoia anticomunista capitaneada por el senador McCarthy, conocida como la "caza de brujas", una campaña política destinada a perseguir la incursión comunista en EEUU. La incertidumbre frente a la realidad surgía cuando los personajes despertaban un día para descubrir que sus parientes mas cercanos, amigos y vecinos no eran realmente 
quienes parecían ser. Una metamorfosis producida por la cercanía de una vaina vegetal cuyo origen se sitúa en "el más allá", la cual sustituye al sujeto original por un Otro. Un proceso de deshumanización a partir del cual los individuos actúan de forma mecánica, sin emociones de ningún tipo y movidos por un objetivo común que les lleva a colaborar juntos con el fin de integrar al resto de la humanidad.

Este argumento, en el que unos seres se expanden por una geografía que no es la suya perturbando su equilibrio, ha sido objeto de diferentes lecturas. En una muy probable se apunta en el sentido de una crítica a la asfixiante atmósfera policial provocada por la persecución política que afectó a un gran número de profesionales de Hollywood.

Estas políticas de corte fascista, como la referida, se basan en la delimitación y demonización conceptual del otro, y en la idealización y demarcación geográfica de una comunidad en la que se pretende instaurar un discurso único, de forma que aquel que no se adscriba a esta coyuntura supone un enemigo a combatir. Un requisito previo es la configuración formal de los invasores y de aquellos que, englobados en un modo de vida común (como el American Way of Life), se sienten amenazados. Este arquetipo del fortificado frente a la irrupción del Otro pertenece a toda una tradición social, política y narrativa que se remonta a los orígenes de los Estados Unidos (Clave dramática y discurso político del 11-S", en Revista Latina de Comunicación Social, 64-2009, pág. 926937).

Una iconografía fundacional que encuentra su mejor representación en el western clásico norteamericano. En figuraciones como la rueda de caravanas para protegerse de los "indios", que se han ido ampliando hasta llegar a la noción de "esfera" desarrollada por Peter Sloterdijk, o en películas como Centauros del desierto (The searchers, John Ford, 1956), un clásico incontestable que tiene una lectura otra de corte racial, tal y como se señala en el documental Reel Injun, indios de película (Reel Injun, Neil Diamond, Catherine Bainbridge, Jeremiah Hayes, 2009), planteado como una denuncia del modo maniqueo en que han sido retratados los nativos americanos en el cine, sobre todo en el de Hollywood.

\section{El agujereado de lo real}

Como intrusos. Así son recibidos los africanos que protagonizan La Blessure. Una entidad extraña que con la sola presencia de sus cuerpos o el pronunciamiento de sus nombres denuncia la condición normalizada de un mundo regido por las complacientes leyes de la doméstica e interesada seguridad. Esta es la propuesta que le es ofrecida al espectador: abrir los ojos a la representación de una realidad que es omitida de aquella que permanece presa del orden simbólico dominante para, a través de sus imágenes, tomar contacto, si quiera cognoscible, con lo Real que esos hechos refieren. Un encuentro imposible, a sabiendas de que el presente y la muerte solo pueden ser representados por ausencia, que es emplazado por el tejido cinematográfico. Pues, lo Real, tal y como Lacan lo concibió, es por naturaleza inaprensible e insoportable.

Conviene que recordemos el pasaje en el que Lacan retoma uno de los sueños referidos por Freud en su Interpretación de los sueños para ejemplificar ese irrealizable encuentro con lo Real. Se trata de aquel en que un padre, agotado después de acompañar junto a la cama y durante días a su hijo enfermo, decide descansar en la habitación contigua a aquella en que se halla el cadáver. En sueños, ve cómo su hijo se le acerca, le toca el brazo y le susurra al oído un reproche:

\footnotetext{
"Padre, ¿no ver que estoy ardiendo? A
} estas palabras despierta sobresaltado, 
observa un gran resplandor que ilumina la habitación vecina, corre a ella, encuentra dormido al anciano que velaba el cadáver de su hijo y ve que uno de los cirios ha caído sobre el ataúd y ha prendido fuego a una manga de la mortaja" (Freud, 1981, p. 656)

Lacan pone el acento en el despertar, en ese momento en que, cuando se ha materializado en sueños el deseo de volver a ver a su hijo, algo sobresalta al.

Siguiendo esta línea de investigación se puede leer el interesante estudio de Antonio Sánchez-Escalonilla "Hollywood y el arquetipo del atrincherado. Clave dramática y discurso político del 11-S", en Revista Latina de Comunicación Social, 64-2009, pág. 926937.

padre:

¿Qué es? No sólo la realidad, el golpe, el knocking, de un ruido hecho para que vuelva a lo real sino algo que traduce, en su sueño precisamente, la casi identidad de lo que está pasando, la realidad misma de una vela que se ha caído y que está prendiendo fuego al lecho en que reposa su hijo. ¿Qué despierta? ¿No es, acaso, en el sueño, otra realidad? Esa realidad que Freud nos describe así: Dass das Kind an seinem bette steht, que el niño está al lado de su cama, ihn am Arme fasst, lo toma por un brazo, y le murmura con tono de reproche, um ihm vorwurfsvoll zuraunt: Vater, sieshst du denn nicht, Padre, ¿acaso no ves, dass Ich verbrenne, que ardo? (Lacan, 1987, p. 65).

Esta apelación del niño al padre se da en una recreación de la realidad, pero se trata de una "realidad fallida", que solamente puede darse en sueños. De ahí la pregunta de Lacan:

¿Dónde está, en este sueño, la realidad? -si no es en que se repite algo, en suma más fatal, con ayuda de la realidad (...). Así el encuentro, siempre fallido, se dio entre el sueño y el despertar, entre quien sigue durmiendo y cuyo sueño no sabremos, y quien sólo soñó para no despertar". (..) El despertar nos muestra el despuntar de la consciencia del sujeto en la representación de lo sucedido. (Lacan, 1987, pp. 66-67).

El esquivo encuentro con lo Real se da, por tanto, en ese "entre", en esa zona de incertidumbre, en ese despertar entre sombras en movimiento, en ese terreno abonado a lo fantástico en que la franqueza de los hechos puede ser (entre) vista por el despuntar de la conciencia del sujeto en la representación de lo sucedido.

La Blessure se abre con un despertar y finaliza con un corte brusco que deja la pantalla en negro varios minutos hasta el final, mientras se continúa escuchando el relato que del trayecto que lleva a muchos inmigrantes a Europa -cruzando desiertos, diferentes países y el estrecho de Gibraltarhace Amadu, uno de los inmigrantes que ocupaban el edificio. Un abrir y cerrar de ojos. Una ensoñación consciente movida por el deseo de una toma de posición crítica. Un tiempo en el que se le ofrece al espectador la oportunidad de compartir una experiencia a través de la compleja representación de una realidad que se asemeja cada vez más a la formulada en La invasión de los ultracuerpos:

En la sociedad consumista tardocapitalista, la 'vida social real' adquiere de algún modo la consistencia de un fraude escenificado, en el que nuestros vecinos se comportan en la 'vida real' como actores y extras... De nuevo, la verdad última del universo capitalista utilitarista y desespiritualizado es la desmaterialización de la propia 'vida real', su inversión en un espectáculo espectral. (Zizek, 2008, p. 17) 
Una puesta en escena formulada para reemplazar la abstracción real constituida por la economía capitalista $-y$ que se pretende naturalizar como la Realidad- para crear un (entre)espacio que posibilite la puesta en cuestión de dos universos polarizados por los horizontes opuestos de lo colectivo y de lo propio. Que es, también, el "despuntar de la conciencia" a una realidad social condenada a vivir en penumbra. La de aquellos desheredados sentenciados a asumir el estatuto de un muerto viviente.

\subsection{A modo de palimpsesto}

Para comprender mejor esta condición que determina a los protagonistas de $L a$ Blessure, y sin ningún afán de ser exhaustivos, proponemos un repaso a la representación del zombi en el cine, sobre todo a las primeras producciones que incluyeron esta inquietante figura, que nos ayudará a complementar el análisis de la situación por la que atraviesan los personajes y el modo en que ésta ha sido formalizada en la pantalla, prestando atención a la codificación que de los negros se hizo en estas películas y que perviven en videojuegos de temática zombi como Resident Evil 5, bajo el inquietante título de Bienvenido a África.

Partiendo del análisis textual de determinados fragmentos, nos proponemos trazar trayectos visuales intempestivos de manera que el poner en relación elementos aparentemente distantes entre sí - en nuestro caso, fragmentos de La Blessure y de los primeros filmes que trataron la temática zombi - propicie un efecto de exilio, un distanciamiento crítico que abra una perspectiva nueva. De tal modo que sus imágenes puedan así "ser entendidas como procesos de significación y codificación cultural, cobrando sentido a través del lugar que ocupan en contextos más amplios de significación" (Castro, 2013, p. 38). Un método rizomático, en los términos expuestos por Deleuze y Guattari, en el que el sentido no vendría determinado por ningún tipo de vínculo dogmático o de conclusión totalizante, sino que más bien sería el resultado de rastrear de forma alternativa, fragmentaria, por diferentes momentos $y$ entremedias de construcciones imprevistas, aleatorias, a partir de las cuales (de los choques en expansión que se dan en los intersticios del territorio a analizar) se originan imágenes nuevas en la mente de aquel cuya mirada se convoca. Diálogos a través del tiempo, de las formas; en el interior de un laberinto. Un método que supone un proceso arqueológico, entendiendo la arqueología en el sentido que le da Foucault en el libro Las palabras y las cosas. Una arqueología de las ciencias humanas: no una ciencia que se sostenga sobre un terreno seguro, no un discurso a seguir, sino diferentes territorios a descubrir.

Un camino que emprendemos siguiendo la sospecha de que la potenciación del espacio off narrativo se conecta por ausencia con los orígenes de aquello que se cuenta. El cine se asemeja a un palimpsesto, de forma que bajo la superficie fílmica fulguran los espectros de otros tiempos, las huellas de otras historias que no se pueden borrar del todo. Es lo que Gérard Genette llamó "la transtextualidad", es decir, "todo lo que pone a un texto en relación con otro, sea de modo manifiesto u oculto" (Genette, 1982, p. 81). Un proceso de hibridación dialógica que constituye al objeto textual en el cruce de una multiplicidad simbólica. Dado que, siguiendo a Bajtin, nuestro propio lenguaje y nuestras formas de expresión se construyen a partir de las palabras y recursos de otros: "Un enunciado vivo, aparecido conscientemente en un momento histórico determinado, en un medio social determinado, no puede dejar de tocar miles de hilos dialógicos vivos, tejidos alrededor del objeto de ese enunciado por la conciencia ideológico-social" (Bajtin, 1989, p. 94). 
Conscientes de lo arriesgado de nuestra propuesta nos imaginamos como Alicia en la sala de las puertas. El camino a seguir no va a ser el más evidente y va a exigir de aquel que lo transite un cambio de perspectiva. Pero nos guía el convencimiento de que será el más provechoso. Aquel que nos posibilite una mayor apertura de sentido.

\section{La dimensión fantástica en La Blessure}

Esta puesta en cuestión del orden simbólico dominante, esta apertura de sentido que propicia la duda frente a la realidad, se da, de nuevo, en el terreno de lo fantástico. En el caso de la película que nos ocupa, recurriendo a la conjunción del género fantástico con estrategias propias del documental, como la elección de unos actores no profesionales que han vivido unas experiencias similares a las que interpretan ante la cámara. Contribuye a situarnos en el terreno de lo fantástico una fotografía que desarrolla un sugerente juego de luces y sombras. Una fotografía saturada a verdes y azules, con lo que gana en luminosidad la piel de los protagonistas, que son así destacados artísticamente con una belleza casi espectral, al igual que las escasas pertenencias que poseen (una tela, una olla, un cuchillo), que adquieren un insólito valor estético.

La potenciación del fuera de campo, a su vez, estimula nuestra imaginación para fantasear más allá de cuanto vemos. Bien sea con respecto a los avatares vividos por los protagonistas en su viaje a Europa, a la vida de los familiares que dejaron en su país o a los problemas a los que se enfrentaron al llegar a Francia, y que podemos ir reconstruyendo mentalmente a través de sus palabras, como a la vida que transcurre al otro lado del squat, que podemos intuir a partir de indicios, de los sonidos que se cuelan a través de los muros. Además, como hemos dicho, el grupo de africanos que protagonizan el film están investidos de una ambigüedad que los constituye desde el momento en que penetran en un territorio en el que son recibidos como extraños. Como tales, se ocultan, viven en penumbra, siempre bajo la amenaza de ser descubiertos, de ser desalojados o deportados. Hay otro espacio en el que se mueven libremente, en el que incluso duermen: un cementerio.

Su existencia se encuentra escindida entre una vida que dejaron atrás y otra que está por realizarse. La condición intermedia es la del fantasma, "la del desvío, la de una ocultación indiscriminada" (Fernández Gonzalo, 2011, p. 12). Aquella que desvela los horrores que se ocultan bajo la apacible cotidianidad (Terciopelo azul (Blue Velvet, David Lynch, 1986) o detrás de una cifra o de términos como "cupos de ilegales". Un estado que, digámoslo ya, les confiere la categoría de zombis. Un estadio fronterizo entre la vida y la muerte. Un estar desenfocado, si por estar enfocado se entiende el ajustarse a unos parámetros legitimados y organizados por la dinámica estructural que organiza la sociedad. Pues, lo zombi representa "lo inmediato que carece de nombre, la presencia que no acaba de concretarse en el sortilegio de la unidad, que no se refugia en el lenguaje, sino que se sostiene por una dispersión, entre los huecos y laberintos del verbo" (ib., p. 17).

Veamos un ejemplo de la dimensión fantástica de La Blessure. La acción se sitúa hacia el final del segundo bloque, en el squat. Justo después de que uno de los ocupantes interprete a la guitarra una canción argelina que habla del drama de los que cruzan el estrecho de Gibraltar en pateras, y del sufrimiento que padecen las madres al temer por la vida de sus hijos. Mientras, por montaje paralelo, vemos a Papi curar la herida de su mujer, Blandine, quien le 
confiesa su preocupación por la salud de sus hijos cuyo cuidado confió a su madre.

Por corte se pasa a un plano muy oscuro. La poca iluminación que entra por los agujeros practicados en la pared indica que es de noche. Junto a ellos se en el cine encontramos reveladores ejemplos de esta sombría dimensión. Como el descubrimiento, al comienzo de Terciopelo azul (Blue Velvet, David Lynch, 1986), de una oreja cortada junto a un modélico barrio residencial o la visión de los miedos, la discriminación, las injusticias y los rastros de muerte que subyacen en una Europa que se pretende unida, que desencadena un simple y despreciativo gesto - por parte de un joven hacia una mujer de origen rumano que mendiga en la calle- en el largo y ejemplar plano secuencia que abre Código desconocido (Code inconnu: Récit incomplet de divers voyages, Michael Haneke, 2000) adivina una sombra (Foto 1). Cuando comienza a moverse, nos damos cuenta de que es Blandine. Recluida en su habitación, trata de superar la humillación sufrida. No es más que una sombra, un espectro. Su vida está vacía. Más que tratar de sobrevivir parece escenificar su propia muerte. Deambula por la habitación como un animal encerrado. Se detiene un momento y mira a través de una de las aberturas de la pared (Foto 2).

La lógica concatenación del siguiente plano -en el que se ve a un hombre durmiendo con la cabeza apoyada en una tumba- sería por raccord de mirada, haciendo corresponder la mirada de Blandine con lo que le es dado a ver al espectador. De hecho, el encuadre del segundo plano está tomado en la dirección de su mirada. Pero el espectador advierte enseguida que no se da una continuidad espacial y temporal coherente entre ellos. Pues, en el primero es de noche y en el del cementerio es de día. Además, el encuadre no podría corresponder al punto de vista de ella, ya que, en ese caso, debería estar ella también en el cementerio y no en la casa.
Entonces, ¿qué relación hay entre los dos planos? ¿Quién es ese hombre que gusta de dormir junto a las tumbas? Advirtamos que es la segunda vez que aparece en el film, siempre en la misma posición. ¿Se trata de una imagen real dentro del espacio diegético o es imaginada?, ¿es un reflejo del estado de ánimo de la protagonista?, ¿debe el espectador entenderlo como una construcción metafórica de la situación a la que se enfrentan los inmigrantes en Europa?

Este tipo de raccords "abiertos" -Burch distingue otros, como el "raccord de aprehensión retardada"- componen "un cine cuya primera materia sería la misma ambigüedad, en el que el espacio 'real' estaría constantemente puesto en duda, en el que el espectador nunca podría orientarse" (Burch, 2004 , p. 23). El paso de un plano a otro, por tanto, provoca una molestia en el espectador, por cuanto le hace consciente del artificio, de la condición de constructo de aquello que ve en la pantalla. Esta incertidumbre hace que se revuelva incómodo en su butaca, le obliga a participar de forma activa con las imágenes que se suceden ante él.

Recordemos las palabras de Tarkovsky cuando destacaba que "en el arte, las asociaciones más ricas resultan indudablemente de aquellas relaciones asociativas en las que se funden las valoraciones racionales y emocionales de la vida". Siguiendo su argumentación, no cabe más que dejarse llevar por este tipo de composición poética, "perderse en sus profundidades como en un cosmos, donde tampoco hay un arriba y un abajo" (Tarkovsky, 1991, pp. 38-39). 


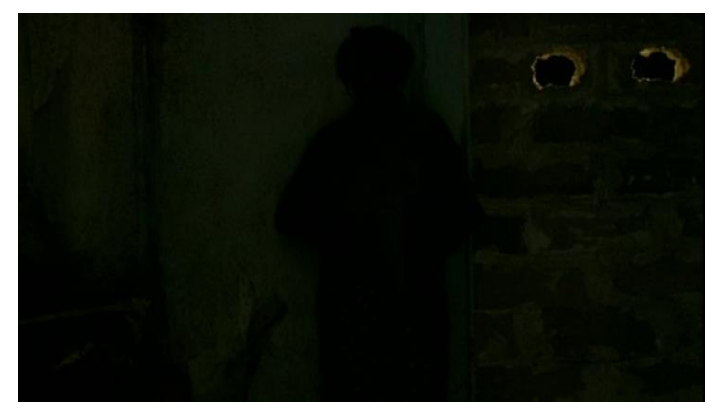

Imagen 1

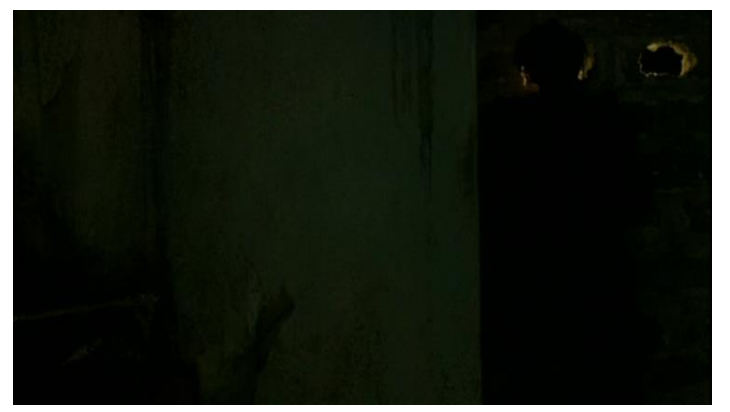

Imagen 2

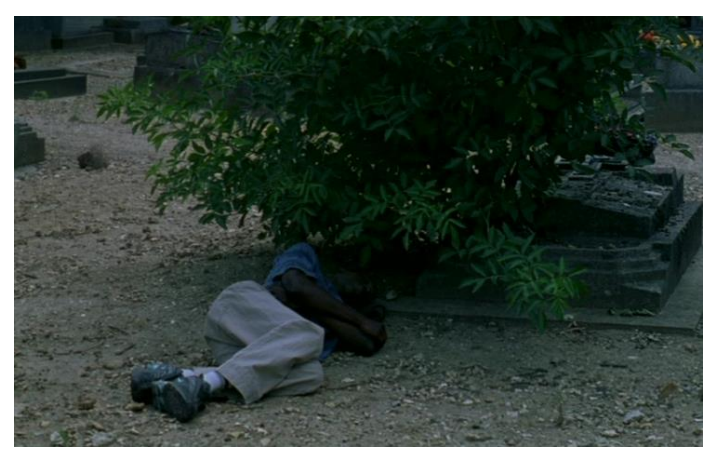

Imagen 3

\section{Un repaso a la configuración clásica del zombi}

\subsection{La legión de los hombres sin alma}

Se considera la primera película de zombis, la legión de los hombres sin alma (White Zombie, Victor Halperin, 1932) aquella que instaura la representación clásica del género. Según la cual el advenimiento del no muerto está ligado al vudú y los ceremoniales animistas practicados por los esclavos negros que fueron llevados a las islas del Caribe. La película narra las peripecias de una pareja de recién casados que viajan a Haití invitados por Beaumont, un extraño personaje que regenta un castillo con la fiel y abnegada ayuda de un grupo de zombis, a los cuales utiliza como mano de obra barata (Foto 5).

El cochero que conduce a la desdichada pareja al castillo proporciona una ajustada descripción del zombi: "Muertos vivientes, por las noches los sacan de sus tumbas y los hacen trabajar en los campos y en las refinerías de azúcar". Como esclavos se les ve trabajar en las mazmorras del castillo, empujando una enorme rueda de molino o transportando pesadas cargas sobre sus cabezas (Foto 5). Cuatro años después los hermanos Halperin rodaron La rebelión de los muertos (Revolt of the Zombies, Victor Halperin, 1936), en la que los zombis son encarnados en soldados camboyanos inmunes a las balas del ejército francés durante la Primera Guerra Mundial. Este ilimitado poder provocará el conflicto entre aquellos que quieren hacerse con la fórmula que posibilita la metamorfosis

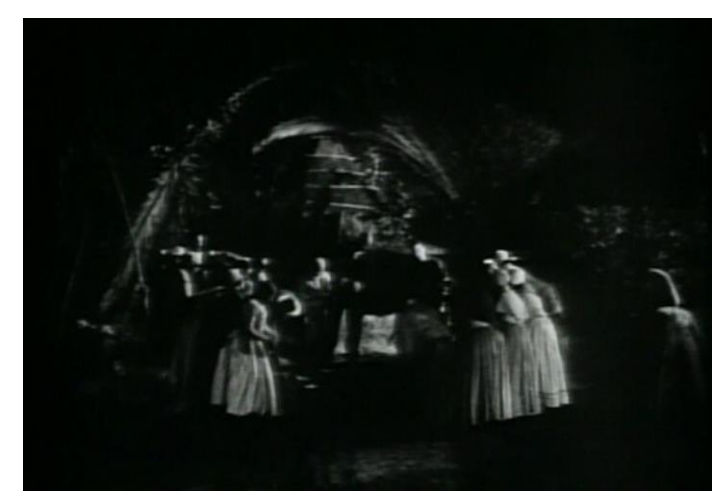

Imagen 4

ROS, F.A.: El otro y su plasmación fantasmática: una lectura transversal de la blessure, de 


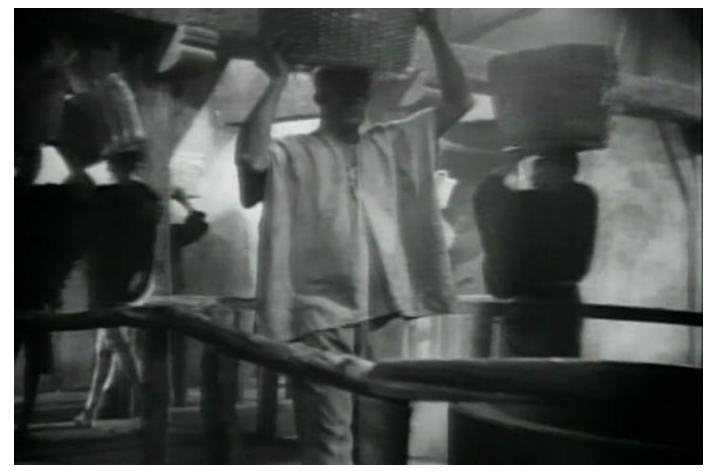

Imagen 5

En la imagen 4 sobre la que se inscribe el genérico de White Zombie se puede ver a un grupo de nativos que cavan la tierra al ritmo de los cánticos y la música propios de algunas zonas de África. Una reconocible letanía a ritmo de percusión -que nos transporta, por ejemplo, a las películas de Tarzan- que inscribe al film en la atmósfera de exotismo, primitivismo y misterio atribuible a lo desconocido.

Como se puede ver, en estas primeras películas los zombis están condenados a obedecer los dictados de aquellos que ejercen un poder absoluto sobre sus acciones. El estado catatónico en el que están sumergidos les coloca a merced de un ente superior. Además, en ambas, el zombi se presenta como el elemento desestabilizador que altera la apacible e idílica convivencia matrimonial de la pareja protagonista. Cualquier rendición a una pulsión de deseo sexual que ponga en peligro esta norma tendrá consecuencias fatales. El zombi, por tanto, se vincula a la trasgresión de un orden social que se considera ejemplar. Y su origen se sitúa fuera del territorio en el que ese modelo se pretende asegurar. Sanchez-Biosca ha destacado la capacidad que tiene la metamorfosis para manifestar la frontera entre lo monstruoso y lo ordinario, para rasgar el velo de una tranquilizadora uniformidad social, así como la relevancia teórica que tiene en la cultura occidental:
La atracción que ejerce esta figura nace de la suspensión que provoca en las identidades que cualquier sociedad considera fundamentales para su propia seguridad y futuro $y$ que, inevitablemente, sólo determina por oposición con otras entidades, seres y formas: los dioses y los hombres, lo masculino y lo femenino, lo vivo y lo muerto, lo joven y lo viejo. La metamorfosis gusta, pues, de poner en tela de juicio la identidad según los parámetros considerados clave en una época y entorno cultural dados. Por este carácter inquisitivo para con las certezas del sentido, atenta contra la estabilidad misma de cualquier cultura, aunque probablemente también la confirma en sus límites al apurarlos, pues sabemos que no existe civilización que no necesite trabajar su imaginación en las fronteras de lo monstruoso para mejor reforzar lo que considera normal (Sánchez-Biosca, 1995, p. 150).

\subsection{La contingencia de lo monstruoso}

La contingencia de lo monstruoso que se oculta bajo el aparente encanto de las cosas es advertido al inicio de $Y o$ anduve con un zombi ( $I$ Walked with a Zombi, JACQUES TOURNEUR, 1943) por Paul Holland (Tom Conway), dueño de una plantación de azúcar, a Betsy Connell (Frances Dee), la enfermera encargada de cuidar a la esposa, durante el trayecto en barco que les lleva a San Sebastián, en las Antillas. En un momento en que ella se recrea extasiada ante la belleza que le rodea, él le apercibe: "No es una maravilla. [A los recién llegados] todo les parece precioso porque no entienden el significado de las cosas. Los peces voladores no saltan porque sí, sino de terror ante los peces grandes que les persiguen para engullirlos. La luminosidad del agua la producen millones y millones de diminutos cadáveres. Es el brillo de la putrefacción. Aquí no existe la belleza. Solo muerte y decadencia". 
Si analizamos la secuencia completa, confirmaremos el lugar en que se imprime esa perturbadora aberración.

Découpage de la secuencia.

1. Abre fundido. En el océano. Plano General. Travelling de acompañamiento del velero que lleva a la protagonista al Caribe (Foto 1).

2. Fundido encadenado. El sonido del viento se funde con un leve cántico que se escucha casi en susurros. Plano de conjunto en el que aparecen unos nativos (¿habría que decir esclavos?) en primer plano. Tras ellos, el timonel $\mathrm{y}$, al fondo de espaldas, un hombre que pronto sabremos que se trata de Paul Holland (Foto 2).

3. En el eje. Plano de conjunto del timonel y Paul Holland, que mira a la izquierda del encuadre. Betsy en off: "Creo que fue tan solo un par de días antes cuando yo conocí al señor Paul Holland en Antilla. Cuando embarcamos para San Sebastián" (Foto 3).

4. Continúa la voz en off. Plano americano de Betsy que mira a la izquierda del plano. Betsy en off: "Todo era tal como lo había imaginado". Betsy mira al cielo (Foto $4)$.

5. Punto de vista de Betsy. Continúa la voz en off. PG del cielo estrellado. Betsy en off: "Mientras miraba las enormes y resplandecientes estrellas podía sentir la brisa cálida..." (Foto 5).

6. Continúa la voz en off. PM de Betsy, en off: "rozándome las mejillas. Cada vez que respiraba, algo dentro de mi exclamaba: 'iQué maravilla!' Se escucha a Paul en fuera de campo: "No es una maravilla". Betsy se gira en la dirección de la voz (Foto 6).

7. $7=4$. Raccord de mirada. Desde la parte izquierda, Paul se acerca a Betsy hasta quedar frente a ella. Betsy: "Ha leído mi pensamiento, señor Holland". Paul: "Es muy fácil leer el pensamiento de los recién llegados. Todo les parece precioso porque no entienden su significado". A continuación explica lo que hemos detallado anteriormente. Los dos miran en la dirección de un fuera de campo indecible. Betsy, mirándole a él: "No puede ser que piense así". Los dos miran hacia el cielo (Foto 7).

8. $8=5$. Punto de vista de los dos. Continúa la voz de él en fuera de campo. PG del cielo en el que se ve cruzar una estrella fugaz. Paul: "Todo lo bueno muere aquí,..." (Foto 8)

9. $9=7=4$. Los dos se miran. Paul: "...incluso las estrellas". Paul se gira para desaparecer por la izquierda del encuadre (Foto 9).

10. Raccord de dirección. Plano de conjunto similar a 3 , pero más cerrado, en el que el grupo de nativos aparece en primer plano ocupando la mitad inferior del encuadre. Están royendo unos huesos con las manos. Paul entra en campo por la derecha, caminando por la parte superior del encuadre hasta detenerse de espaldas en la mitad del mismo (Foto 10).

11. $11=6$. Betsy mira fijamente en la dirección, fijada por el raccord, en que se encuentra Paul. Betsy: "Me resultó muy desalentadora la manera en que interrumpió mis pensamientos. Había crueldad y dureza..." (Foto 11).

12. $12=3$. En una composición idéntica. Paul permanece de espaldas. Continúa la voz de Betsy en fuera de campo: "en su voz. No obstante, hubo algo en él que me gusto. Algo limpio...” (Foto 12)

13. $13=11=6$. Betsy: “ $\ldots y$ honrado, pero herido. Gravemente herido". 


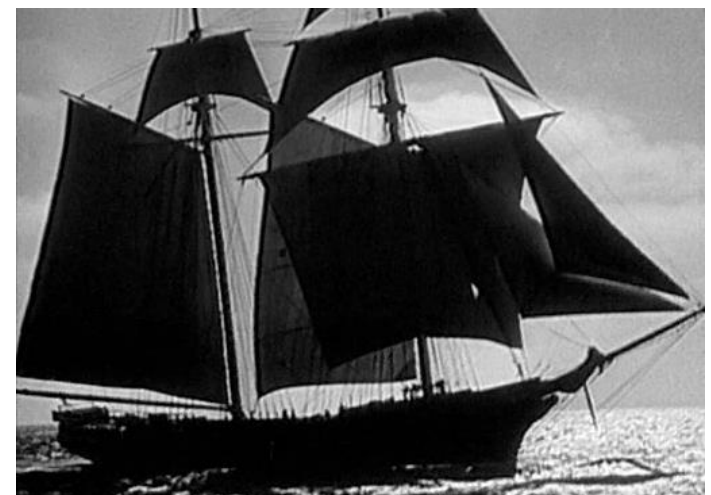

Foto 1

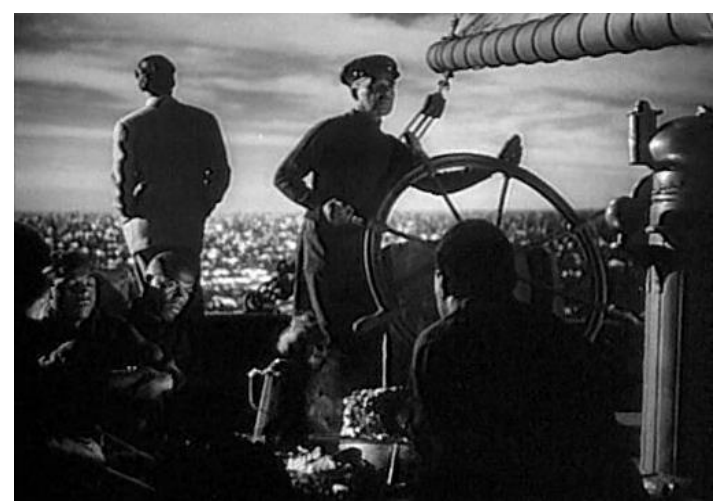

Foto 2

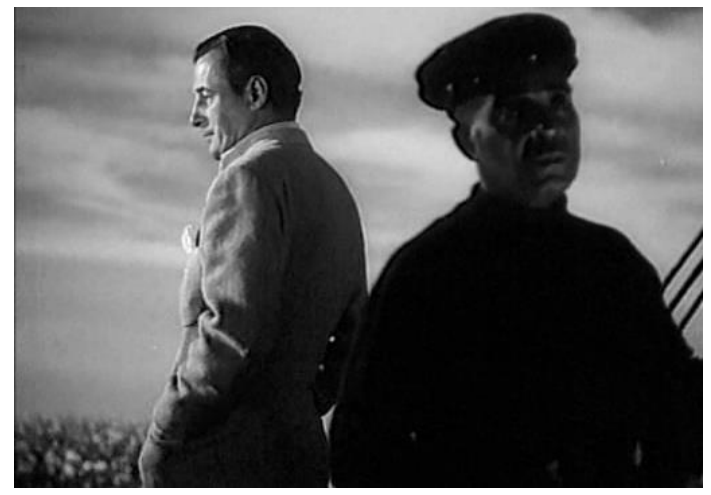

Foto 3

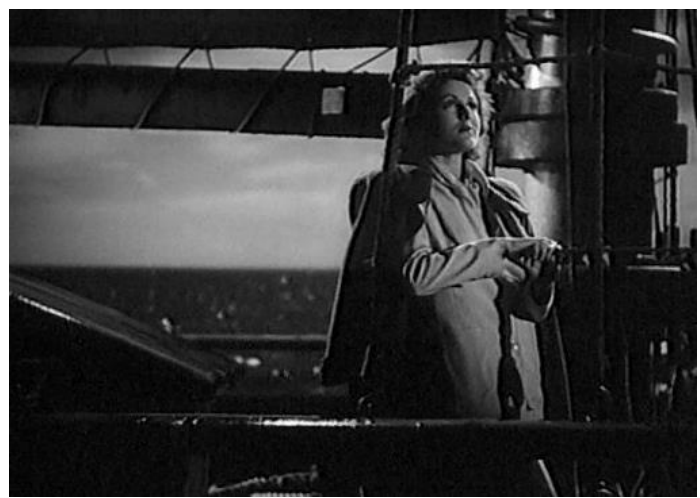

Foto 4

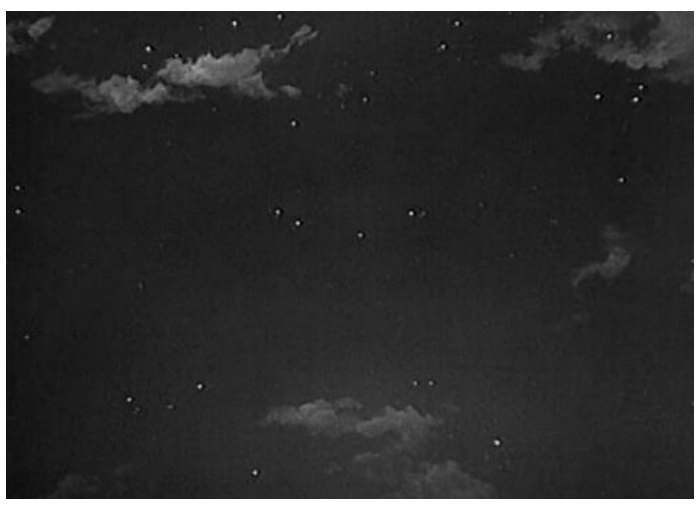

Foto 5

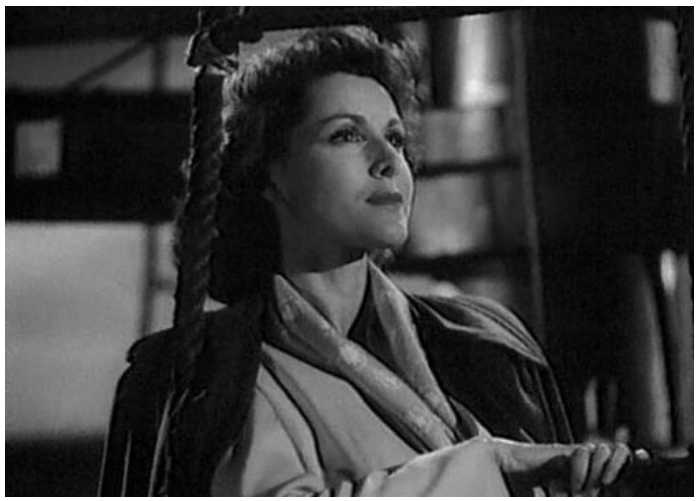

Foto 6

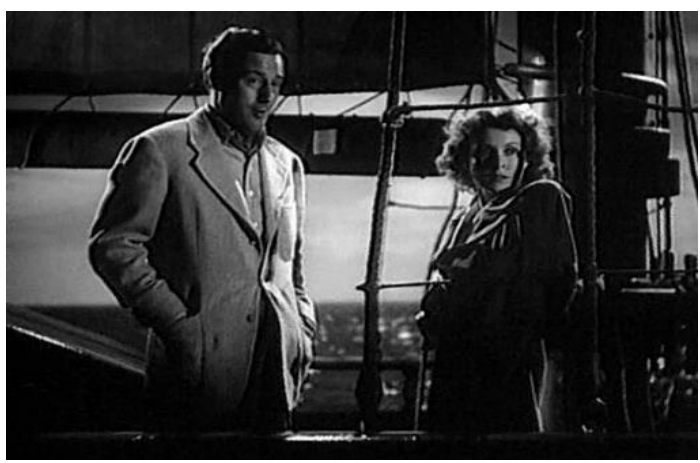


Foto 7

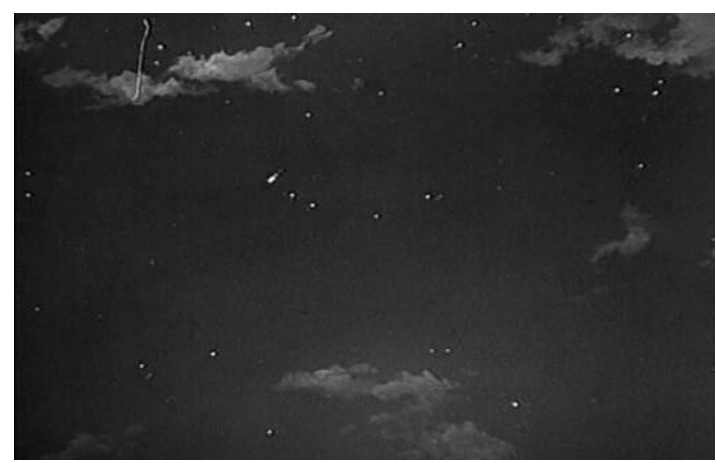

Foto 8

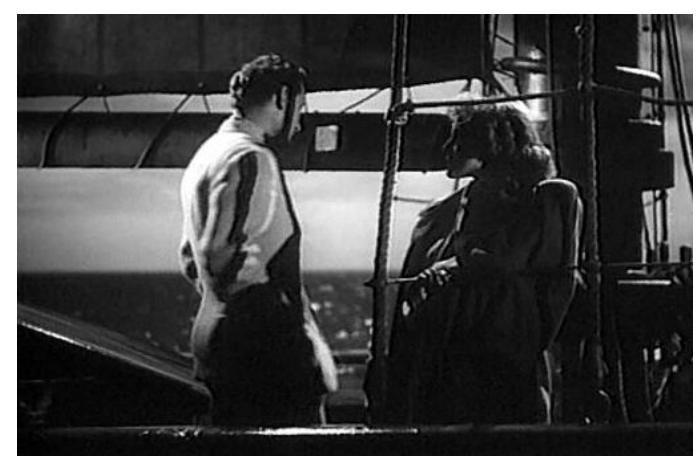

Foto 9

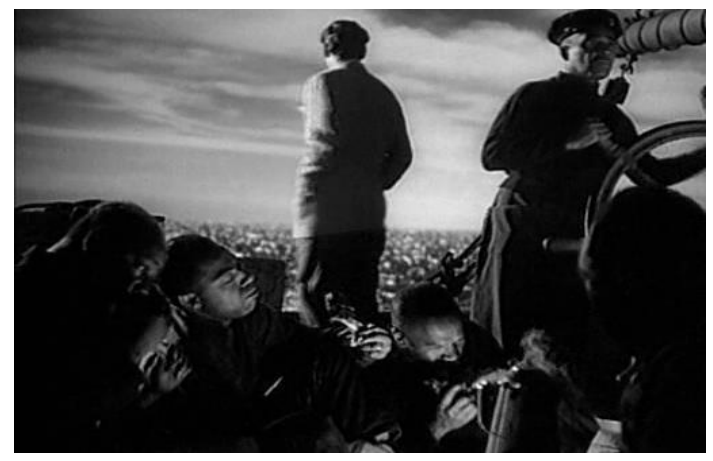

Foto 10

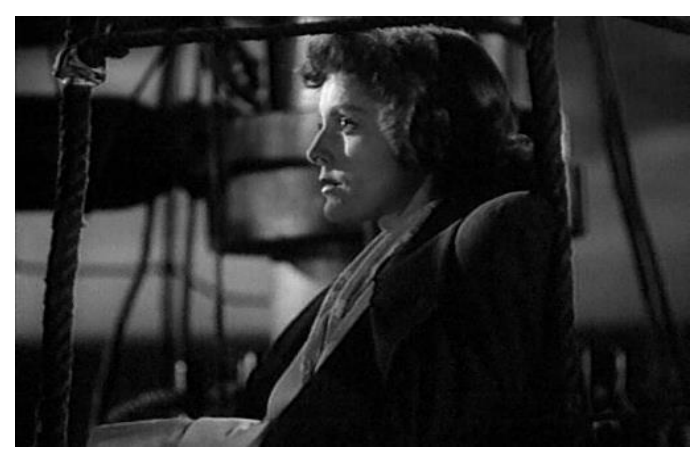

Foto 11

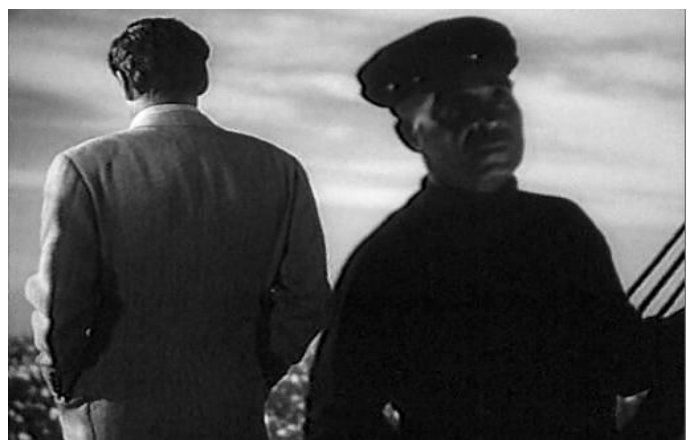

Foto 12

Si nos fijamos en la diferencia entre el plano 2 y el plano 10, apreciaremos cómo el leve reencuadre que se lleva a cabo sobre el eje pone el acento en los hombres que comen en la parte inferior del encuadre y en la figura de Paul. En el plano 2 se da una composición equilibrada en la que destaca, sobre todo, la rueda del timón y el hombre que la guía. Aunque la primera figura que atrae la mirada es la de Paul, que ocupa la esquina superior izquierda. Iniciando una línea transversal que lleva al hombre que se sienta de espaldas en la esquina inferior derecha. El resto de hombres se sitúan entre sombras, sin apenas captar la atención de la mirada. En cambio, en el plano 10 se logra una clara división del encuadre en dos mitades. Una zona de luz, la superior, en la que Paul mira al horizonte, y otra de sombras, la inferior, en la que un grupo de africanos come en una actitud que remite inevitablemente a las escenas de canibalismo recreadas por el cine.

Recordemos que el plano anterior se cierra con la parte final de la reflexión en la que Paul alude al horror que se amaga en la parte invisible de cuanto les rodea: "Aquí no existe la belleza. Solo muerte y decadencia". Por corte se sucede el plano 10 en el que Paul entra por la derecha de forma que parece caminar por esa zona en tinieblas mientras su silueta se recorta altiva sobre el cielo. Luces y sombras, belleza y monstruosidad, orden y 
desorden, progreso y primitivismo. Su figura de espaldas, anónima, se alza confiada por encima de los peligros que acechan en lo más ignoto, mientras el destino le lleva a la conquista de nuevos mundos. Una representación que remite inevitablemente al colonizador, a esa figuración que tan bien representó el personaje de Robinson Crusoe: un individuo que "poseía ya todas las cosas de que podía disfrutar: yo era el señor del lugar (...) ya que todo estaba sometido a mi poder. Por dondequiera ejercía un imperio despótico; no tenía rival ni competidor que me disputase el mando o la soberanía" (DEFOE, D. (1994). Robinson Crusoe. Barcelona: Orbis/Rizzoli, pág. 101, citado por MÉNDEZ RUBIO, Antonio (2012)).

La herida que, según sospecha Betsy, sufre Paul está relacionada con esos peligros a los que se enfrenta todo aquel que se atreve a adentrarse en territorio extranjero. Como se puede comprobar según avanza el film, la enfermedad de su mujer no es otra que la catatonía inducida por un rito vudú la misma noche en que decidió abandonarlo por su hermanastro (¿Influenciada, tal vez, por las extravagancias y la laxitud de costumbres del lugar?). De nuevo, la transgresión del orden establecido va ligada a la presencia del zombi, y la mujer vuelve a ser el foco del conflicto.

La leyenda heroica de la familia pequeño-burguesa que se adentra en el "país de los caníbales" es analizada por Barthes en Bichín entre los negros a partir de un artículo publicado en la revista Match (Barthes, 2009, pp. 56-59). Una historia "estimulante" que se sostiene en el convencimiento de que "el negro asusta (...). Sin la presencia implícita de este riesgo, la historia perdería toda su virtud de impacto, el lector no sentiría miedo". De esta manera, las aventuras de este niño, que viaja con sus padres a África y termina sometiendo a "los comedores de hombres", "descansa sobre el enfrentamiento patético del cuerpo blanco y de la piel negra, de la inocencia y de la crueldad, de la espiritualidad y de la magia" (que encuentra en cine de la primera mitad del SXX).

El grupo de africanos que vemos en La Blessure han llegado a Francia después de completar un viaje lleno de riesgos. Una aventura que continúa en suelo francés por la permanente amenaza que se cierne sobre ellos. La enunciación se sitúa también del lado de los que irrumpen en un territorio extraño, pero en este caso no se trata de dominadores, sino que, de nuevo, los africanos vuelven a ser los dominados. Esta inversión se advierte al comienzo del film, momento en que la "inminencia de una presencia" que supone el fuera de campo se condensa en una amenaza, no en su promesa (COMOLLI, 2010, p. 73). La inscripción del horror latente se concreta, en este caso, en el cuerpo policial. Recordemos el primer segmento del filme, parte del cual ya comentamos anteriormente.

Este enfoque colonialista, que encuentra en los ritos y costumbres de los individuos de raza negra el contrapunto exótico y atroz que legitima su autorizada forma de vida, no se ciñe a cierto cine de la primera mitad del SXX. Por el contrario, encontró su vertiente más obscena e ignominiosa en toda una serie de películas de producción italiana filmadas en los años 60 y 70, y anunciadas bajo la etiqueta de Shockumentary. En realidad, se trataba de falsos documentales de motivación pseudo-antropológica que reunían todo un compendio de escenas a cada cual más cruel, $\mathrm{y}$ que se presentaban como tomadas directamente de la realidad. La serie se inauguró con Este perro mundo (Mondo cane, PAOLO CAVARA, GUALTIERO JACOPETTI, FRANCO PROSPERI, 1962), donde el folklore y las tradiciones de los lugares más recónditos se entremezclan con el sadismo y el salvajismo expuestos con toda crudeza. De Jacopetti y Prosperi son también Africa addio (1966) y Addio zio Tom (1971). A las que siguieron Hombres salvajes, bestias salvajes (Ultime grida dalla Savana, ANTONIO CLIMATI, MARIO MORRA, 
1974) y Mundo caníbal (MONDO CANNIBALE, RUGGERO DEODATO, 1977). Hasta alcanzar el súmmum con Holocausto caníbal (CANNIBALE HOLOCAUST, RUGGERO DEODATO, 1980).

En el primer plano, la respiración de un hombre que duerme se entremezcla con los sonidos que provienen de la calle -voces, golpes, el ruido del tráfico, el piar de los pájaros. La llamada de Blandine desde el aeropuerto anuncia la promesa de un encuentro. Tras el trayecto en metro, Papi llega al aeropuerto. Su paso por la terminal es filmado en un largo travelling en posición de contrapicado. Con lo que se ensalza el momento situando al personaje por encima del plano visual. De forma que se ve a Papi caminar imponente por un gran espacio vacío en el que resuenan sus pasos y que, en contraste con aquel en que vive, parece un escenario de ciencia-ficción. El encadenamiento del siguiente plano supone un corte brusco, una oposición frontal a la determinación de Papi, que instaura la amenaza en la figura del policía de fronteras. El paso de un PA en movimiento, y en el que el cuerpo del personaje se recorta sobre un gran espacio, a un PP fijo, en el que resalta la ausencia de sonido y la expresión severa del agente, advierten inmediatamente del peligro.

De igual forma, hay que destacar la contraposición entre las formas redondeadas y, por tanto, más flexibles y acogedoras que predominan en el plano de la terminal y la abundancia de líneas rectas en sentido vertical que refuerzan la resistencia policial. Una resistencia que no se agota con el policía situado en primer plano, sino que parece repetirse hasta el infinito en profundidad de campo.

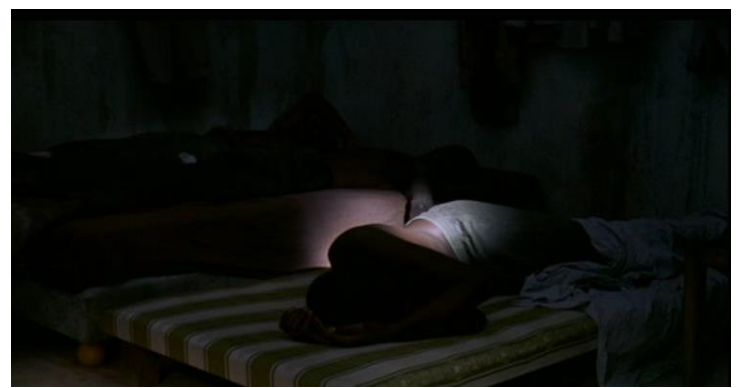

Imagen 1

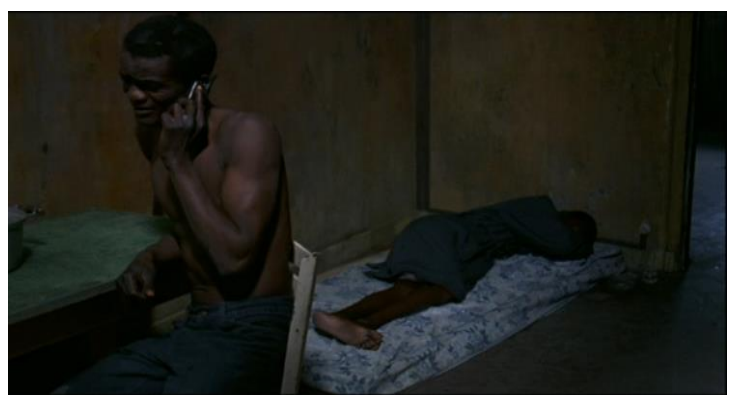

Imagen 2

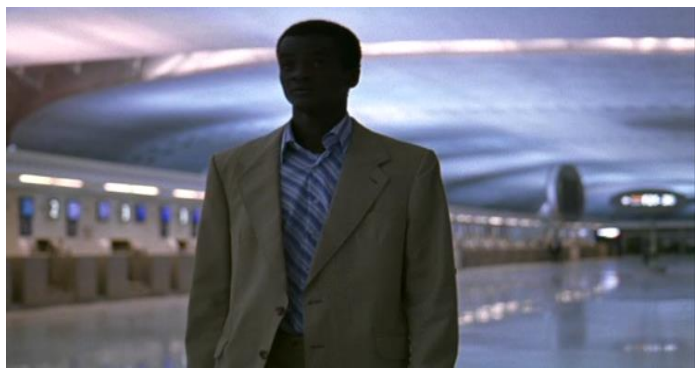

Imagen 3

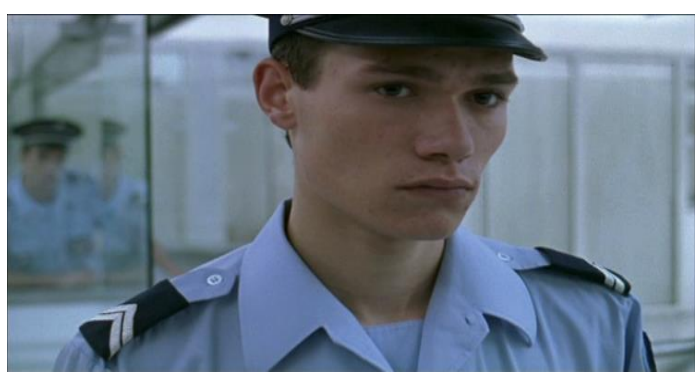

Imagen 4

Por lo tanto, y considerando los films antes comentados, no parece haber salida para aquel cuya presencia cuestiona lo que se sostiene como una certeza, más allá de su papel de comparsa macabra, de reverso oscuro de la sociedad o a cambio de su 
invisibilidad: "La construcción negativa de los otros no europeos es finalmente lo que da una base y sostiene la identidad europea misma" (HARDT, M.; NEGRI, A. (2002). Imperio. Barcelona: Paidós, pág. 123, citado por MÉNDEZ RUBIO, Antonio (2012)).

Su corporeidad e identidad manifiestas siembran la duda, la incertidumbre; fracturan la homogeneidad social sobre la inestable base de una sospecha abriendo el camino a la fantasía. Su lugar, en consecuencia, no puede ser otro que el de los monstruos:

Dialogía, exposición, intemperie de cuerpo. Hablar de metamorfosis descentradas, de articulación de singularidades fragmentarias, de crisis de identidad y de identidad, es hablar entonces, como hacen Hardt y Negri, de la invasión de los monstruos, del retorno de Frankenstein. (Méndez Rubio, 2012, p. 160)

Se da una correspondencia entre esas partículas elementales en que se convierten los cuerpos de los inmigrantes representados en la película. Una relación voluble, quebradiza, como la decisión de mantener un plano o pasar al siguiente. $\mathrm{Y}$ es de esa incertidumbre que surge la crueldad, la injusticia, la opresión, al hacerse evidente ese otro cuerpo, el cuerpo social. Sus cuerpos son vigilados, amontonados, violentados, despedazados. Sus identidades, borradas, ignoradas. Restituirles la dignidad supone darles un espacio y un tiempo propios, escucharles. Sentarse junto a ellos.

La inversión producida en La Blessure supone, en relación con I Walked whith a Zombie, ponerse del lado de los oprimidos, hacer del amenazante fuera de campo el foco de atención. La película de Tourneur construye un espacio diegético según la siguiente disposición: residencia -campos, atravesados por un camino señalizado y vigilado por el ceremonial vudú - espacio inhóspito de la comunidad negra. De forma que este último se constituye en el amenazante fuera de campo de la residencia, puesto de manifiesto de forma auditiva a través de los cánticos y la percusión musical y visual, en forma de sombras inquietantes que se proyectan sobre la casa y los personajes. Mientras que en La Blessure quedaría así: lugar ocupado por la comunidad negra cementerio - espacio inhóspito de la comunidad blanca. La presencia de este último se hace sentir de igual forma mediante sonidos y juegos de sombras.

\subsection{La noche de los muertos vivientes}

La noche de los muertos vivientes (Night of the Living Dead, GEORGE A. ROMERO, 1968) supone también una inversión respecto a la configuración clásica del muerto viviente. Pues, cuando George A. Romero retoma el género en 1968, el primer zombi que aparece en la película está representado en la figura de un señor de mediana edad y raza blanca vestido con traje chaqueta, eso sí, ya raído después de que abandonara su tumba. Pero, quizás, lo más llamativo sea que el personaje que centra todo el protagonismo, el único superviviente del grupo de personas que se refugian en una casa cercana al cementerio, sea un joven de raza negra (Attack the Block (JOE CORNISH, 2011)).

Pero lo que más nos interesa destacar es el final de la película, pues en él se da un cambio de registro, de modo de representación, del cine a la fotografía. Una operación formal que abre el film a un fuera de tiempo y de lugar que, si bien no puede ser reconstruido, como demostró Claude Lanzmann, sí puede ser emplazado exorcizando la memoria del espectador, apelando al poder que tienen las imágenes para dialogar entre ellas, para abrir espacios dialógicos en un tiempo y un espacio heterogéneos, indeterminados. 
Recordemos la última secuencia del film. Con el día llegan la policía y varios grupos de voluntarios que, armados con escopetas, van a la caza del zombi (Foto 1). Por montaje paralelo, vemos cómo Ben se despierta (Foto 2). Está solo en el sótano. El resto están todos muertos. La policía trae perros rastreadores mientras los voluntarios van abatiendo a los zombis sin que éstos apenas ofrezcan resistencia (Foto 4). Ben escucha los disparos y decide salir del sótano (Foto 3). Lentamente, se acerca a la ventana para comprobar lo que está ocurriendo afuera (Foto 5). Al verle, el hombre que da órdenes a los voluntarios le indica a un compañero que le dispare justo entre los ojos (Foto 6). Ben cae fulminado (Foto 7). "Buen disparo. Vayan a buscarlo. Otro más para el cementerio", señala el cabecilla (Foto 8). Es justo en ese momento que la película cambia de registro (Fotos 9-16). El resto de la historia se reconstruye mediante la sucesión de fotos fijas, como si se tratara de un diaporama. El cuerpo de Ben es trasportado por varios hombres con la ayuda de ganchos metálicos, amontonado en una pila de cuerpos y, finalmente, quemado.

Dos producciones recientes presentan unas interesantes propuestas que subvierten la imaginería racial más estereotipada. Una de ellas es Attack the Block (Joe Cornish, 2011), un film en el que unos peculiares alienígenas con pinta de gorilas invaden un barrio marginal del sur de Londres, de mayoría de población negra, donde se las verán con un grupo de pandilleros adolescentes acostumbrados a tener que buscarse la vida. Uno de ellos hará su propia interpretación de la invasión: "Creo que los ha enviado el Gobierno. Son mutantes creados para matar chicos negros. Primero ponen las drogas, después ponen las armas y ahora mandan monstruos. No les importa. Estamos tardando en matarnos entre nosotros y han acelerado el proceso". La otra son los videoclips realizados por Romain Gavras para la rapera M.I.A. En Born Free presenta de forma ultra acelerada y violenta una persecución policial segregacionista en la que los individuos a eliminar son los pelirrojos. En Bad Girls toda la parafernalia gangsta se ve subvertida al protagonizar las coreografías un grupo de mujeres islámicas, mientras que la testosterona queda en manos de individuos que encajarían a la perfección en cualquier noticia sobre terrorismo islamista.

En este fotomontaje hay, además, una indagación, una intención enunciativa que se va a proyectar sobre las imágenes. La cámara utiliza el zoom para penetrar en la foto, para ofrecer el detalle. Hay panorámicas dentro de la foto, hay raccord de miradas entre fotos. Hay, en definitiva, una organización entre planos con el fin de dar un sentido. Pero, como le ocurría al fotógrafo de Blow-Up (Deseo de una mañana de verano) (Blow-Up, Michelangelo Antonioni, 1966), cuanto más ampliamos una foto menos visible es el detalle, al tiempo que hay un espacio que desaparece. Pero esa foto ampliada adquiere una textura nueva, granulada, borrosa, en la que se confunden los contornos con el entorno. Una imagen en la que se ha impreso el paso del tiempo, el tiempo del revelado y el tiempo de la historia, en la que se hacen visibles las huellas de otras imágenes fijadas en la memoria, reales o no.

Así, liberadas de unas coordenadas espacio-temporales concretas, las imágenes fotográficas adquieren un carácter fantasmagórico, memorial, lírico, de acuerdo con la lectura que Didi-Huberman hace de Walter Benjamin: "Por sus posibilidades técnicas de encuadre (es decir de desencuadres), de puesta en serie y de fragmentación (es decir de desmontajes y de remontajes), la fotografía vuelve visible o, más bien, ilumina todo un mundo 'en que analogías, encuentros de acontecimientos inconcebibles están a la orden del día'. 
Benjamin llama a esto una capacidad de lirismo" (Didi-Huberman, 2008, p. 291). De esta forma, las asociaciones no se hacen esperar, la imagen revela todo su poder para reclamar diferentes momentos de la historia por medio del montaje y la dialéctica, entendida por Benjamin como "testigo del origen", quien reclamaba un "estilo filosófico" a la hora de remontar la historia, considerado como un "arte de lo discontinuo, por oposición a la cadena de deducciones" (BENJAMIN, Walter (19311938). "Lettres à Brecht", en Essais sur Brecht, Paris, La Fabrique éditions, citado por DIDI-HUBERMAN, Georges (2008)) En este sentido, hay que recordar que por aquel entonces, en 1968, los conflictos raciales habían llegado a su cenit en los Estados Unidos. No en vano, las batidas organizadas por los humanos para aniquilar a los resucitados producen un estremecedor sentimiento de familiaridad con las persecuciones a que fue sometida la raza negra en aquel país a finales de la década (GARCÍA ROMERO, Ángel (1994). "La noche de los muertos vivientes", en Quatermass, especial Ciclo de Cine Fantástico de Bilbao, junio, 25-31, citado por Fernández Gonzalo (2011)).

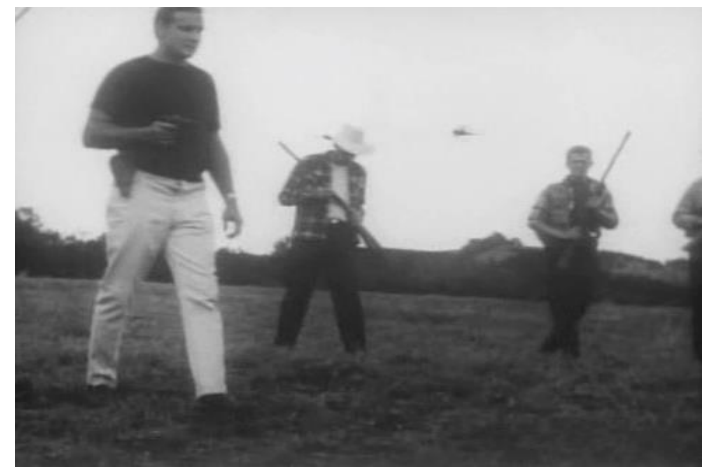

Foto 1

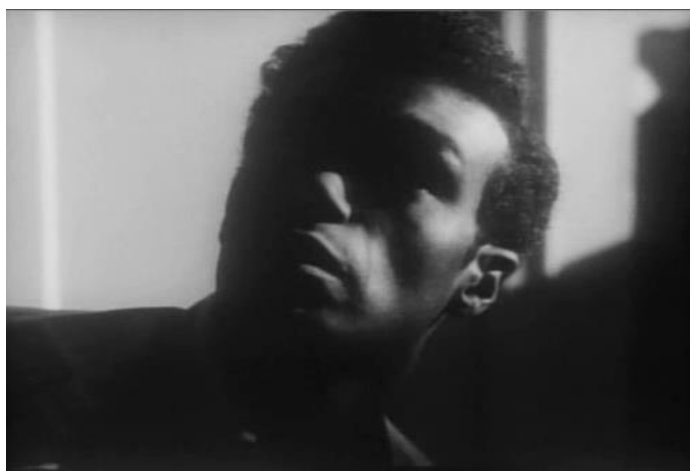

Foto 2

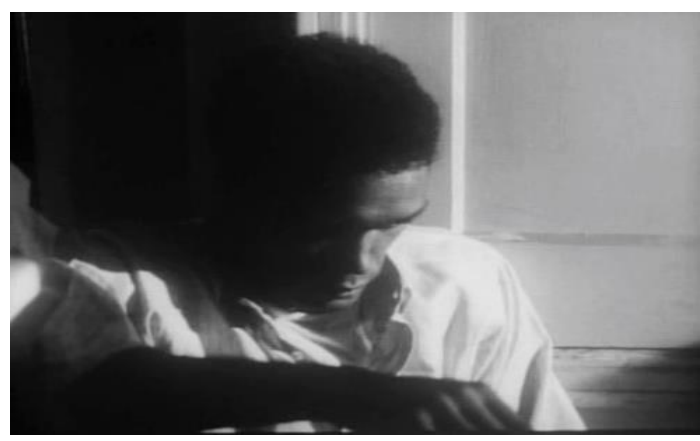

Foto 3

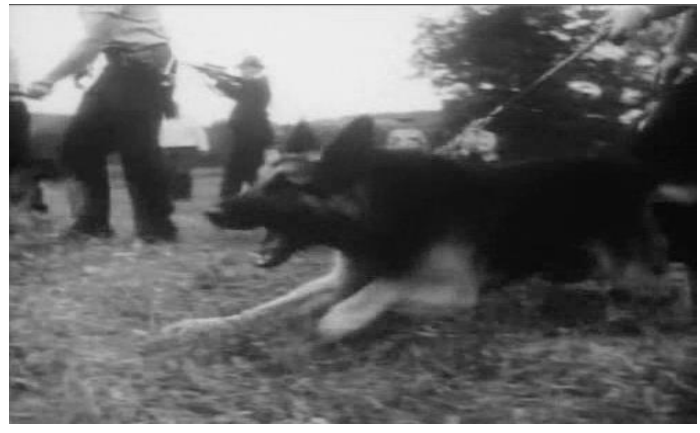

Foto 4

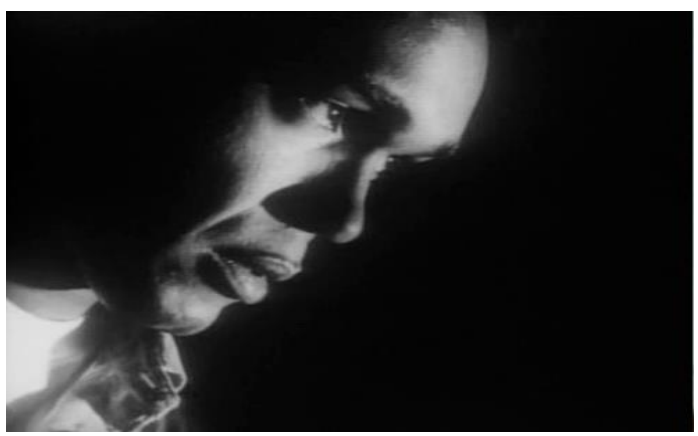

Foto 5 


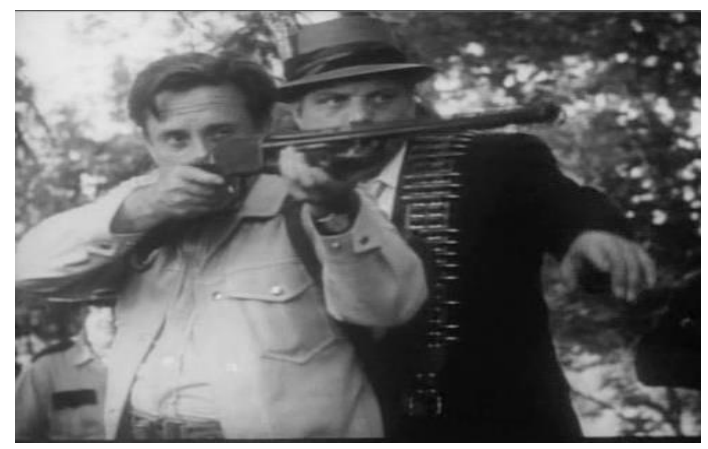

Foto 6

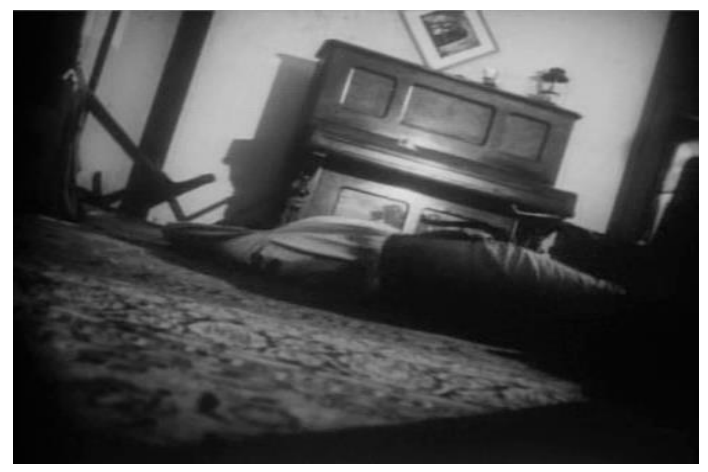

Foto 7

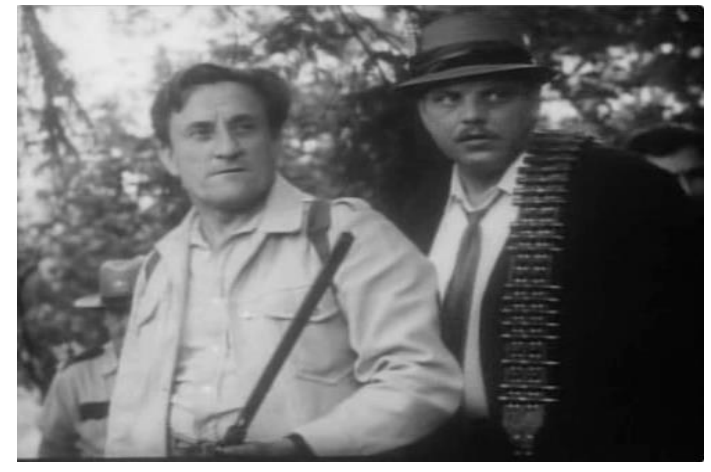

Foto 8

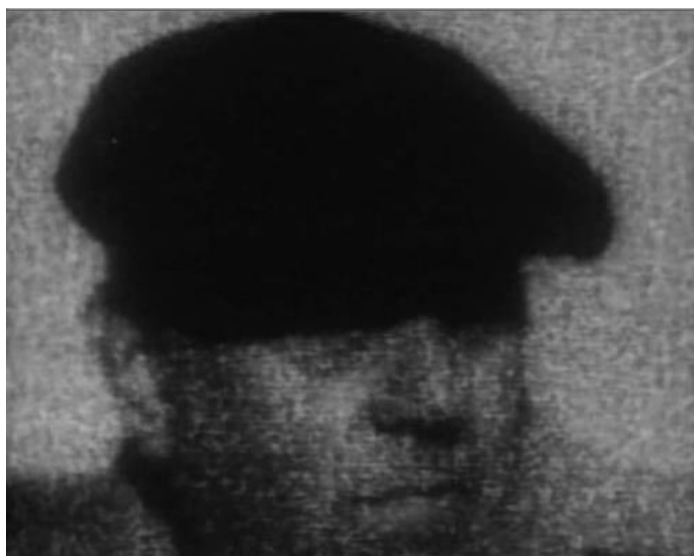

Foto 9

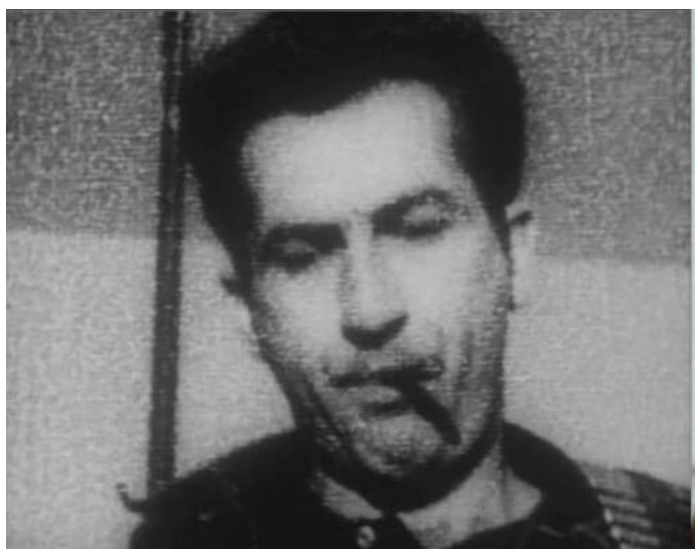

Foto 10

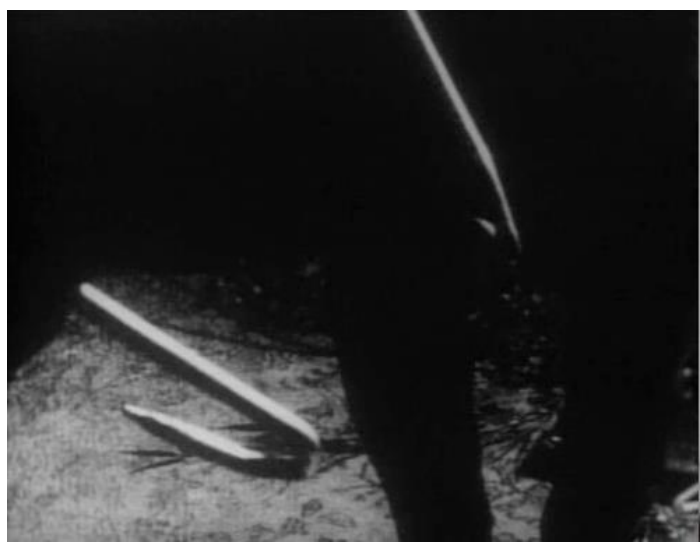

Foto 11 


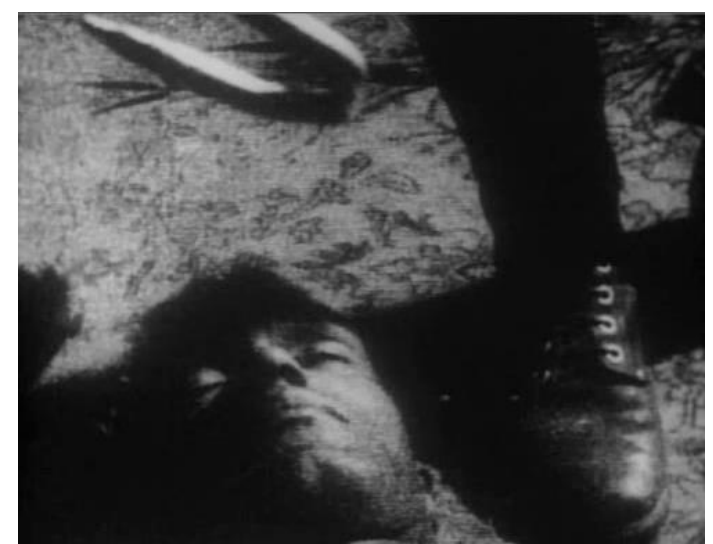

Foto 12

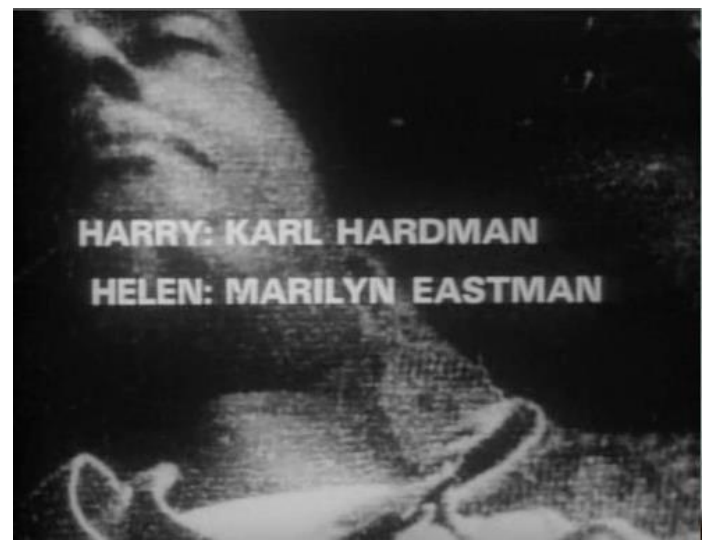

Foto 13

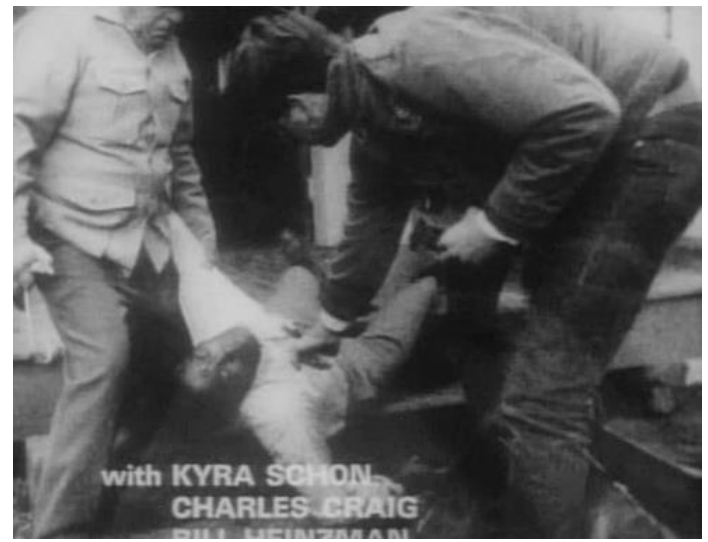

Foto 14

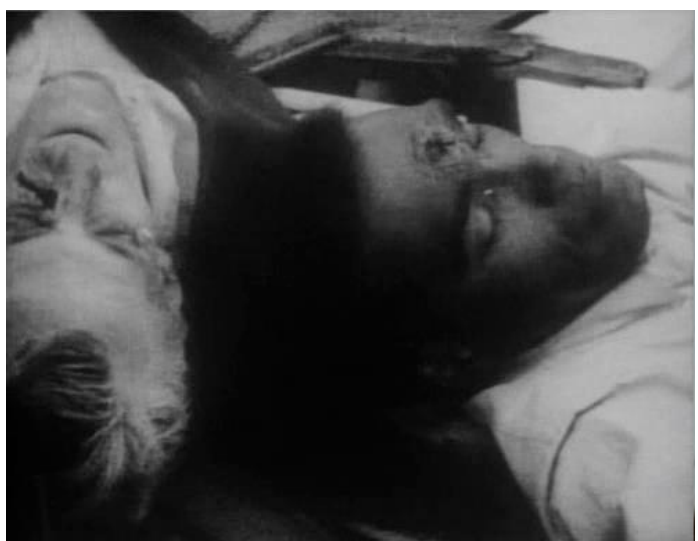

Foto 15

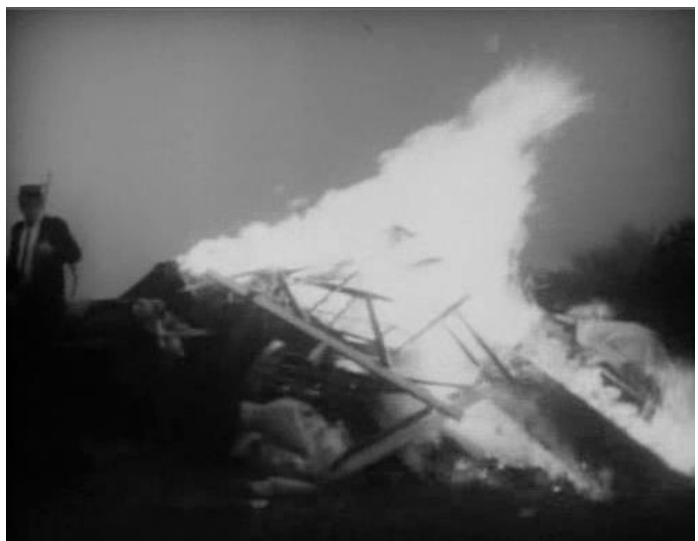

Foto 16

\section{Reflexiones finales}

En el capítulo 3 A de Histoire(s) du cinema, sobre un primer plano de Pier Paolo Pasolini Godard anota: "Un pensamiento que forma / una forma que piensa", insistiendo en la capacidad que tienen las imágenes (y las palabras) de crear nuevas formas y en cómo éstas, por sí mismas o en relación (inestable) con otras, nos estimulan a pensar, a generar ideas nuevas, extraviadas. ¿Y no se abre paso así a nuevos espacios, nuevas interpretaciones, otras oportunidades de vida autoconsciente?

En esta investigación hemos proyectado itinerarios guiados por el poder que tienen las imágenes para convocar a otras tantas que pueblan nuestro imaginario. Lo iniciamos 
siguiendo la pista que apunta en la dirección de que el conflicto de las ideas se dirime en la reinvención de las formas. Lo hemos ejemplificado analizando fragmentos de la película en función del papel jugado por cada uno de esos componentes. Hemos proyectado también trayectos intempestivos que han ampliado las posibilidades dialógicas y significantes del film atendiendo a las asociaciones, reverberaciones y fricciones que se dan entre los elementos que lo componen, y a la capacidad que tienen las imágenes para interactuar con otras imágenes, descubriendo sentidos imprevistos, osados.

En Imágenes, a pesar de todo DidiHuberman se preguntaba, a partir de cuatro fotografías tomadas en agosto de 1944 en Auschwitz-Birkenau, si ver una imagen puede ayudarnos a conocer mejor nuestra historia, y colegía que para saber hace falta pensar. En el abismo que se abre entre el ver y el saber se da el magnetismo que posibilita una construcción de sentido, una toma de posición, una idea. Una idea defendida, siguiendo la cita que de Benjamin hace DidiHuberman,

$$
\begin{aligned}
& \text { como configuración y no como } \\
& \text { concepto, ley o tesis unívocos: 'Las } \\
& \text { ideas son a las cosas lo que las } \\
& \text { constelaciones son a los planetas. Esto } \\
& \text { primero quiere decir esto: no son ni su } \\
& \text { concepto ni la ley'. En consecuencia, } \\
& \text { sólo cobran sentido por sus posiciones } \\
& \text { respectivas, una manera de decir que no } \\
& \text { atañen ni a la universalidad ni a la razón } \\
& \text { clasificatoria, sino a su lugar afirmado } \\
& \text { en un montaje dado. (Didi-Huberman, } \\
& \text { 2008, p. 154) }
\end{aligned}
$$

En los intersticios de ese montaje, en ese abrir y cerrar de ojos que apuntábamos al inicio, en ese espacio de incertidumbre, surge la ocasión de un encuentro con lo Real. Es ese entre el que posibilita un despuntar de la conciencia. De haber una salida, ésta se encuentra el la mente del espectador.

\section{Bibliografía}

1. BAJTIN, M. Teoría y estética de la novela. Madrid: Taurus, 1989.

2. BARRENECHEA, Ana María. "Ensayo de una Tipología de la Literatura Fantástica (A propósito de la literatura hispanoamericana)". Revista Iberoamericana, 80, 391-403. 1972.

3. BARTHES, Roland. Mitologías. Madrid: Siglo XXI, 2009.

4. BURCH, Nöe. Praxis del cine. Madrid: Fundamentos, 2004.

5. CASTRO, Maribel. El remake en la fotografía construida. Revista Fotocinema, 6,5-41, 2013.

6. COMOLLI, Jean-Louis. Cine contra espectáculo, seguido de, Técnica e ideología (1971-1972). Buenos Aires: Manantial, 2010.

7. DELEUZE, Gilles; GUATTARI, Félix. Mil mesetas: Capitalismo y Esquizofrenia. València: Pre-textos, 1994.

8. DIDI-HUBERMAN, Georges. Cuando las imágenes toman posición. Madrid: A. Machado Libros, 2008

9. FERNÁNDEZ GONZALO, Jorge. Filosofía zombi. Barcelona: Anagrama, 2011. 10. FOUCAULT, Michael. Las palabras y las cosas. Una arqueología de las ciencias humanas. Buenos Aires: Siglo Veintiuno, 1968. 
11. FREUD, Sigmund. Obras Completas, tres volúmenes. La interpretación de los sueños, vol. I. Madrid: Biblioteca Nueva, 1981.

12. GENETTTE, Gérard. Palimpsestes: la littérature au second degré. Paris: Éditions du Seuil, 1982.

13. LACAN, Jacques. El Seminario. Libro XI. Los cuatro conceptos fundamentales del psicoanálisis. Barcelona: Paidós, 1987.

14. MÉNDEZ RUBIO, Antonio. La desaparición del exterior. Zaragoza: Editorial Eclipsados, 2012.
15. SÁNCHEZ-BIOSCA, Vicente. Una cultura de la fragmentación. Pastiche, relato y cuerpo en el cine y la televisión. València: Textos, 1995.

16. SLOTERDIJK, Peter. Esferas I. Burbujas. Madrid: Ediciones Siruela, 2003. 17. TARKOVSKY, Andrei. Esculpir en el tiempo. Madrid: Ediciones Rialp, 1991.

18. TODOROV, Tzvetan: Introduction à la littérature fantastique. Paris: Seuil, 1970.

19. ZIZEK, Slavoj. Bienvenidos al desierto de lo real. Madrid: Ediciones Akal, 2008. 